\title{
2 灯 1 灯切り替えを利用した蛍光ランプの時比率調光制御
}

\author{
○貞永信明，小林 幹 (工学院大学) \\ Fluorescent Lamp Dimmer by Time Ratio Control which Adopts Switching \\ from Two Lamps to One Lamp \\ ONobuaki Sadanaga, Miki Kobayashi (Kogakuin University)
}

キーワード : 蛍光ランプ, 調光制御, 省エネルギー

\section{1. はじめに}

近年, 地球環境問題が社会的に憂慮され，照明も工 ネルギー消費を削減する動きに期待が高まっている。 省エネルギーの方法として, 照明を隇光する調光制御 がある。本研究は 2 灯用照明器具をモデルにして, 蛍 光ランプの時比率調光制御に加え, 1 灯を消灯する調 光制御を組み合わせた方式を考案しその特性を測定し た。提案方式の有用性が明らかになったので報告する。

\section{2. 高周波点灯回路の回路模成}

図 1 は実験に使用した基本的なハーフブリッジイン バー夕回路である。調光回路からゲート駆動回路へ無 動作期間の信号を送り，この期間の長さを変えて時比 率調光制御を行っている。また, Tr3 を OFFすること で下方のランプを消灯し 2 灯点灯から 1 灯点灯に切り 替えることができる。

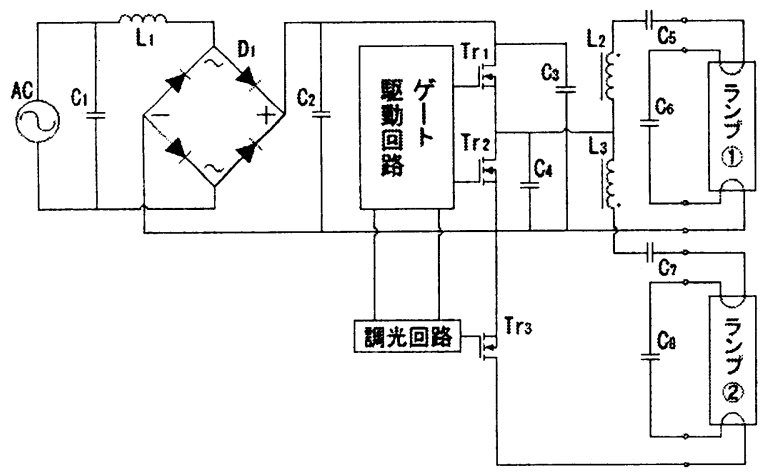

図 1. 2 灯点灯回路の構成図

\section{2 灯 1 灯切り替え調光方式}

表 1 に示すように 2 灯 1 灯切り替え方式は, 2 灯の ランプを同等の時比率で調光する方法と異なり, 明る
さ50\%以下では 2 灯から 1 灯のみの点灯に切り替えて 時比率を 2 倍にして 2 灯分の明るさを得る方法である。 今回, 表 1 にある 2 通りの調光方法の比較を行った。

\section{2 奵調光之 2 奵 1 奵切り替え調光の比較}

表 1 の各調光制御で, 平均通流率を変えた場合の単 位電力当たりの明るさを図 2 に示す。この結果はラン プと照度計を $8 \mathrm{~cm}$ 離して測定したものである。調光度 合いが深くなるほど効率低下は顕著になるが， 2 灯 1 灯切り替え方式は低下率が小さく, 高い効率を維持す る範囲が広いことが分かる。

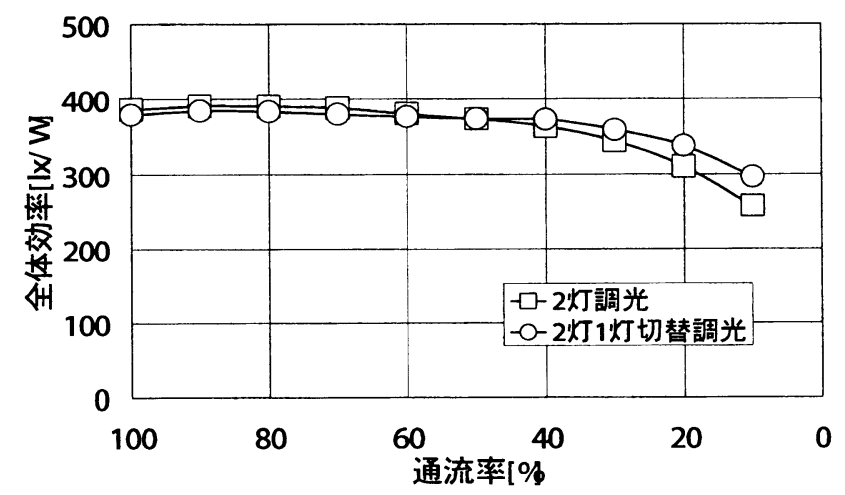

図 2. 調光制御の比較

\section{5. まとめ}

2 通りの制御方法で比較した結果, 2 灯 1 灯切り替 え方式が調光時の効率低下を抑えることができた。こ の方法は明るさ $50 \%$ 以下に 2 灯分の明るさを 1 灯で賄 い, 時比率の OFF 期間を減らすことが可能である。1 灯当りの時比率の割合は大きくなり, 調光度合いを深 くしたときも 2 灯調光方式に比べ, 立ち消えし難くラ ンプの点灯維持に有効であると考えられる。

表 1. 2 灯 1 灯切り替えの調光制御方法

\begin{tabular}{|c|c|c|c|c|c|c|c|c|c|c|c|c|}
\hline \multicolumn{2}{|c|}{ 合計の明るさ(平均通流率)[\% } & 100 & 90 & 80 & 70 & 60 & 50 & 40 & 30 & 20 & 10 \\
\hline \multirow{2}{*}{2 灯調光 } & $\begin{array}{c}\text { 時比率 } \\
\text { [\% }\end{array}$ & ランプ(1) & 100 & 90 & 80 & 70 & 60 & 50 & 40 & 30 & 20 & 10 \\
\hline $\begin{array}{c}2 \\
2\end{array}$ & ランプ゚ 1 灯 & 100 & 90 & 80 & 70 & 60 & 50 & 40 & 30 & 20 & 10 \\
切り替え & $\begin{array}{c}\text { 時比率 } \\
{[\%}\end{array}$ & ランプ(1) & 100 & 90 & 80 & 70 & 60 & 100 & 80 & 60 & 40 & 20 \\
\hline ランプ(2) & 100 & 90 & 80 & 70 & 60 & OFF & OFF & OFF & OFF & OFF \\
\hline
\end{tabular}

